\title{
La imagen de Busiris y Memnón en las fuentes clásicas
}

\author{
Daniel Miguel MÉNDEZ RODRÍGUEZ
}

La caracterización física y adscripción étnica de los egipcios antiguos es una cuestión debatida en la investigación egiptológica desde hace bastante tiempo. Las hipótesis afrocentristas recientes insisten en la negritud de los egipcios. Frente a esta interpretación se encuentran los medios académicos occidentales. Mi propósito es destacar en este contexto una importante fuente de información: la iconografía cerámica helena. A través de ella y de su comparación con las fuentes literarias se analizará cómo eran percibidos los egipcios por sociedades coetáneas. El objeto específico de mi estudio es comparar las distintas fuentes sobre dos personajes paradigmáticos en la mitología griega: Busiris, un monarca egipcio, y Memnón, un gobernante etíope. Con estos objetivos me he centrado en estudiar principalmente los rasgos fenotípicos que aparecen tanto en las referencias de las fuentes literarias clásicas, como en la producción cerámica helénica de los siglos VI-IV a.e.

\section{The image of Busiris and Memnon in classical sources}

The physical characterization and ethnical adscription of the Ancient Egyptians have been topics of great interest in Egyptology research for some time. The afrocentrists' hypotheses insist that the Egyptians were black. Opposing this interpretation we find the western academic media. My objective is to emphasize in this context the importance of one source of information: the iconography of Hellenic pottery. By means of this and its comparison with literary sources it will be possible to analyze how the Egyptians were perceived by contemporary societies. The specific purpose of my research is to compare different sources on two paradigmatic characters in Greek mythology: Busiris, an Egyptian monarch, and Memnon, an Ethiopian ruler. With these objectives, I have mainly focused on the phenotypic features which appear in references from classical literary sources, and also, from Hellenic pottery production of the VI-IV AC centuries.

KEYWORDs: physical characterization, phenotypic features, Busiris, Memnon, afrocentrism, Hellenic pottery

$\mathrm{L}$ a caracterización física de los egipcios antiguos y su adscripción étnica basándose en criterios bioantropológicos es un tema que sigue aún candente, aunque no es nuevo pues ha aparecido varias veces desde el siglo XIX en la investigación egiptológica.
El interés por la craneología y el establecimiento de clasificaciones tipológicas se manifestó a finales del s. XIX en teorías explicativas como la invasión de la raza dinástica de W. M. F. Petrie ${ }^{1}$. En las últimas décadas la cuestión ha surgido de nuevo y ha suscitado un gran interés, provocan-

1. La noción de raza dinástica de Petrie como modelo invasionista argumentativo del devenir de la civilización egipcia aparece en varias de sus obras. Este planteamiento destaca en la interpretación del registro material protodinástico en el que se observan, según él, dos grupos diferenciados de población que presentan características diferentes que los definen. Uno de ellos serían los egipcios del sustrato y el otro, el de esta nueva raza proveniente del suroeste asiático. Véase por ejemplo en: Petrie, 1974a: 59-64; Petrie, 1974b: 49-50.

Fecha de recepción: 28 de enero de 2007

Fecha de aceptación: 25 de junio de 2007 
do un agrio debate historiográfico en torno a los llamativos postulados de la escuela afrocentrista nilótica. Según ellos, la población y la propia cultura del Egipto antiguo fueron conformadas por individuos melanodermos, es decir, negros. La base de su concepción radica entre otros elementos, en su cuestionable identificación entre los términos africano y negro. Además, insisten en que las fuentes literarias clásicas califican a los egipcios de negros ${ }^{2}$. Nuestro propósito es averiguar hasta qué punto otros documentos coetáneos de estos textos y producidos en el mismo contexto cultural son coincidentes. Por eso nos centraremos en un conjunto de imágenes producidas de forma coetánea a esas cuestiones literarias por sociedades helenas.

Pretendemos por consiguiente retomar la cuestión de la definición étnica de los egipcios antiguos desde una perspectiva diferente. El enfoque diferencial viene aportado por varios elementos: por un lado se ha tomado como centro de la investigación dos personajes mitológicos específicos, Busiris y Memnón; por otro, hemos empleado fuentes iconológicas helenas, y por último, se ha comparado y contrastado éstas con las fuentes literarias.

La selección de los sujetos de estudio constituye un factor esencial. En la mitología griega, Busiris y Memnón son los personajes más significativos asociados respectivamente a egipcios y etíopes ${ }^{3}$. Se ha tratado de personificar en ellos el análisis de cómo las sociedades clásicas percibían los rasgos físicos de las poblaciones africanas. Consideramos que la selección es ya de por sí sugerente. Busiris era un monarca egipcio mientras que Memnón era un gobernante etíope. Esto nos podría ayudar a inferir las distintas características asociadas a ellos que pueden observarse en las fuentes. Por un lado podremos observar cómo son concebidos de un modo individual y, por otro, si se manifiestan diferencias entre ellos podrían ser extrapolables a las sociedades de las que provienen.

Las fuentes utilizadas como ya se ha mencionado son de dos tipos: iconológicas y literarias. La fuente iconológica principal ha sido las representaciones en la cerámica helénica. La producción analizada más abundante es la cerámica ática, y sobre todo la de figuras negras y rojas. Por lo tanto se le asocia una cronología que abarca de una forma aproximada los siglos VI y V a.e. También se han empleado piezas de producciones corintias, apulienses, lucanas, lo que implica una mayor amplitud geográfica y del marco cronológico, que llega hasta la segunda mitad del siglo IV a.e. Asimismo se ha estudiado algún documento escultórico, como el friso del Tesoro de los sifnios de Delfos, y algunos espejos grabados.

La metodología de análisis aplicada se ha fundamentado en un estudio iconológico de las representaciones. Éste se ha centrado en los rasgos fenotípicos, es decir, en las características fisiológicas manifiestas como pueden ser la piel, el cabello, la estatura, la morfología craneal, rasgos faciales (nariz, grosor labial, ojos...). Paralelamente se han observado otros tipos de elementos que caracterizan étnicamente a los personajes,

2. En la inmensa mayoría de las alusiones físicas a egipcios en las fuentes literarias se les asocia a vocablos derivados de $\mu \varepsilon ́ \lambda \alpha \varsigma$, que significa oscuro o negro, aunque también se observa el calificativo subfusculus (Amm. Marc. XXII 16, 23), que alude a una coloración más clara respecto a un elemento oscuro o negruzco.

3. Bien es cierto que existen otros personajes egipcios en la mitología griega como Proteo, Teoclímeno, Épafo, Nilo, Belo o Dánao entre otros. Sin embargo, las fuentes literarias no hacen alusión a las características físicas objeto de nuestro estudio, a excepción de Épafo, a quien en un texto (A. Pr. 851) se le aplica el adjetivo grie-

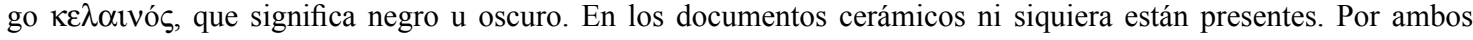
motivos se ha desestimado su análisis en unos parámetros que no son comparables a los de Busiris y Memnón. 
como la vestimenta y otros objetos asociados. No obstante, tampoco se han querido descuidar, entre otros múltiples aspectos, cuestiones como la temática y el contexto (la situación y el entorno funcional de la pieza).

Las fuentes literarias empleadas incluyen a autores tanto griegos como latinos en un marco cronológico que va desde los poemas homéricos hasta el siglo IV d.e. Han sido rastreadas en búsqueda sobre todo de referencias a los rasgos físicos y el entorno cultural que caracteriza a los personajes.

\section{BUSIRIS}

Busiris fue concebido en la mitología clásica como rey de Egipto ${ }^{4}$, aunque hay alguna versión que lo denomina gobernador de una parte de él ${ }^{5}$. Era hijo de Poseidón, aunque su madre varía según el documento: por un lado tenemos a Lisianasa ${ }^{6}$, y por otro a $\mathrm{Libia}^{7}$, hija de Épafo, y éste a su vez, de Zeus. En el episodio mitológico, las fuentes narran que durante cierto tiempo, unos nueve años ${ }^{8}$, afectó a Egipto una gran sequía. Como remedio Frasio 9 , un adivino chipriota, profetizó que cesaría la necesidad y la esterilidad si anualmente se sacrificaba un extranjero a Zeus (o Júpiter según la interpretatio latina). Así hizo Busiris, inmolando como primera víctima al adivino. Posteriormente hizo lo mismo con otros extranjeros que se presentaban en el país, hasta el advenimiento de Heracles. El héroe heleno llegó a Egipto tras haber estado en Libia y haber matado allí a Anteo, que era de hecho hermano de Busiris. En Egipto fue apresado y llevado en procesión para ser ofrecido a Zeus. Al principio, Heracles adoptó una actitud pasiva, hasta el instante en que iba a ser sacrificado en el altar. Fue en ese momento en el que se liberó y asesinó a Busiris, al hijo de éste, Anfidamante, y a los sacerdotes presentes.

\subsection{Busiris en la iconografía}

Las representaciones de este episodio mitológico en las producciones cerámicas se documentan ya desde el segundo cuarto del siglo VI a.e., durante la etapa de las figuras negras, aunque de un modo esporádico. En este siglo VI se observará en piezas procedentes de Samos (o de Rodas), de Caere, y de Atenas, que es el centro de difusión por excelencia y la única polis de la Grecia continental que lo produce. Las últimas representaciones documentadas proceden de la cerámica pintada itálica, destacando los talleres de Lucania y Apulia. Estas producciones no van más allá del siglo IV a.e., ignorándose el episodio según Annie-France Laurens ${ }^{10}$ en época helenística y romana. Por tanto y resumiendo, estas producciones cerámicas se insertan en una cronología que va desde el segundo cuarto del siglo VI a.e. hasta el siglo IV a.e. La tipología en la que podemos clasificar las escenas permite establecer dos grupos diferenciados. El primer tipo es en el que aparece la procesión de Heracles y los sacerdotes, y la presentación del héroe heleno ante Busiris. Se podría considerar una variante de este tipo las escenas en las que se observa el inicio de una acción violenta por el griego. El segundo tipo lo

4. D.S. I 45, 3-4; IV 27, 2-3. Apollod. II 5, 11.

5. D.S. I $17,3$.

6. Apollod. II 5, 11.

7. Isoc. Ep. XI 10-28.

8. Apollod. II 5, 11. Ou. AA I 647-652.

9. Sólo en Ou. $A A$ I 647-652 aparece como Trasio.

10. Lexicon Iconographicum Mythologiae Classicae, III: 151. En adelante LIMC. 
constituyen las escenas en las que Heracles se rebela y lucha, persiguiendo, golpeando y matando a Busiris y a los sacerdotes.

\subsubsection{Primer tipo: Procesión y presentación de} Heracles ante Busiris ${ }^{11}$

En las representaciones del primer tipo aparecen la procesión y presentación de Heracles ante Busiris; son muy escasas en comparación con las del segundo tipo. La pieza más antigua documentada es de producción ateniense, de figuras rojas, que cronológicamente debe ser de mediados o finales del siglo $\mathrm{V}$ a.e. No obstante, la mayoría son piezas apulienses y lucanienses de figuras rojas asociadas a una cronología que va, desde ca. 400 a.e., hasta ca. 340-330 a.e. Aparece en una relativa variedad tipológica de vasos cerámicos: se ha localizado en una crátera, un dino, un ánfora y un quílice.

La escena presenta a Heracles que es llevado con las manos o algún pie atado ante Busiris (fig. 1). Éste suele estar sentado en un trono, con los pies sobre un escabel, aunque también se ha documentado de pie. Va ataviado a veces con una vestimenta que podríamos calificar de orientalizante, con motivos decorativos geométricos (círculos, zigzags, puntillado...). Otras, con un jitón largo y un himatión. Suele llevar los pies calzados con sandalias. Resulta especialmente notable que va tocado con lo que

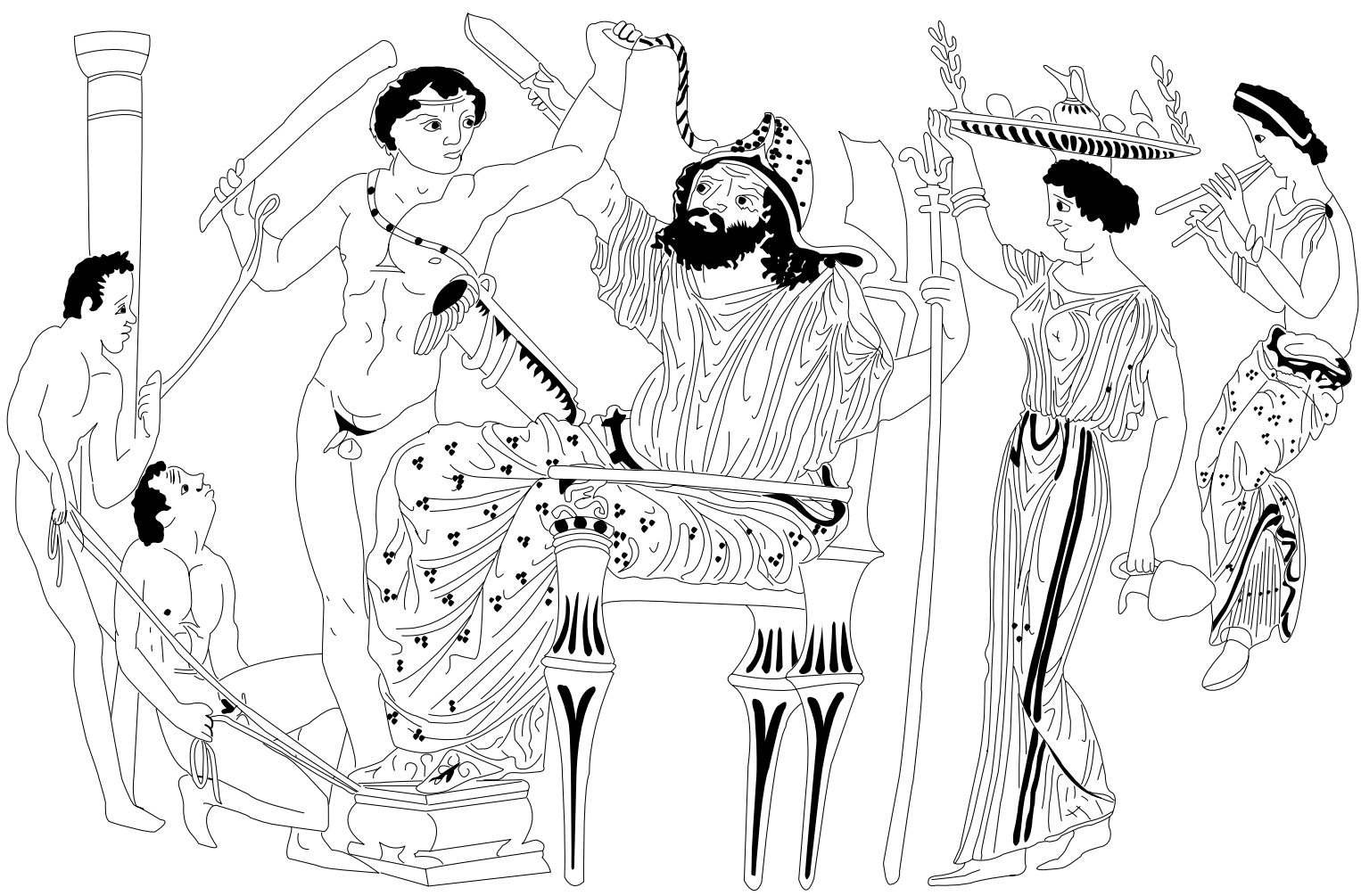

Figura 1. Heracles ante Busiris entronizado. Fragmento de crátera de figuras rojas, ca. 400 a.e. Napoli, Museo Archeologico Nazionale 82276

11. Miller afirma que este tipo iconográfico corresponde a la adopción de un modelo próximo oriental de procesión imperial como la que aparece en la decoración de los palacios persas, y que se enmarca en una persianización de algunos mitos. Véase Miller, 2000: 432. 
asemeja un gorro frigio. Los objetos que le acompañan suelen ser un cetro y la machaira, el cuchillo sacrificial, que suele aparecer en su mano derecha alzada en dirección a Heracles. Físicamente, Busiris es representado barbado, con bigote e incluso con largos cabellos, y sin ningún otro atributo físico que lo diferencie de un personaje heleno como Heracles. Estos objetos y características aparecen también asociadas a la figura de Hades de un modo similar o idéntico en la cerámica coetánea del mismo contexto (apuliense de finales del siglo IV a.e. $)^{12}$, por lo que nos encontramos ante un esquema compositivo que se utiliza para presentar a un monarca, en un caso egipcio y en otro del inframundo. Los sacerdotes y los sirvientes llevan jitones y/o himationes, aunque estos últimos pueden aparecer desnudos. De manera genérica, no hay rasgos físicos diferenciadores muy marcados (sólo el cabello es relativamente largo...). No obstante, esto puede ser así porque nos encontremos ante lo que Snowden considera como mulatos ${ }^{13}$. Por otro lado, hay un ejemplo ${ }^{14}$ en el que se observa una morfología nasal diferenciada (nariz chata) y engrosamiento labial que distingue a estos personajes tanto de Busiris y Heracles, como de algunas sirvientas que aparecen en la pieza.

El contexto sacrificial del episodio mitológico puede entreverse por la presencia en algunas ocasiones del altar, por la machaira antes mencionada $\mathrm{y}$, en alguna escena porque aparecen sirvientas con ofrendas, un oinocoe y tocando el doble aulos, aunque esto último tal vez pudiera considerarse como propio del ambiente cortesano de un monarca o de la celebración de un simposium ${ }^{15}$.

Como conclusión podríamos afirmar de este tipo de escena que corresponde cronológicamente y de manera general a los ejemplos más tardíos (s. IV a.e.) analizados en este trabajo, y que la mayoría de las piezas es de producción centromediterránea (Caere, Apulia, Lucania). Se destaca en ellas el énfasis puesto en determinados elementos para caracterizar al personaje. Las diferencias físicas no son sustanciales respecto a rasgos físicos griegos, y lo único que lo individualiza es estar entronizado, ataviado con una vestimenta orientalizante y llamativamente diferente a la de los demás, y con un gorro frigio, que incide en su carácter oriental. Sin embargo, el resto de personajes de la escena, que se asocian a determinadas actividades serviles, pueden aparecer representados como mulatos.

\subsubsection{Segundo tipo: Ira heraclida y aniquila- ción de los egipcios ${ }^{16}$}

El segundo tipo en que pueden sistematizarse las representaciones de Busiris en las producciones cerámicas es en el que se observa la explosión de furia y violencia del héroe heleno contra Busiris y los sacerdotes, persiguiéndolos, luchando con ellos, golpeándolos y matándolos (fig. 2). Como se vislumbra de lo antes dicho, éste es el tipo más habitual. Se encuentra sobre todo en piezas de producción ática (en mucha mayor medida en las de figuras rojas), aunque también se ha documentado algún ejemplo ma-

12. LIMC IV 2: 219-224.

13. Snowden, 1991: 15.

14. Napoli, Museo Archeologico Nazionale 82276. (= LIMC, III, Pl.127 Bousiris 7).

15. La celebración de un simposium puede corroborarse además por la presencia de una crátera de volutas en una escena de una pieza concreta (Paris, Louvre G 50). Véase LIMC III: 151.

16. Miller considera que este tipo conlleva un cierto carácter paródico o irónico en la inversión del modelo iconográfico egipcio del monarca victorioso sobre los enemigos. Véase Miller, 2000: 417. 
nufacturado en Caere. Las piezas se enmarcan en un período cronológico que va de un modo aproximado desde mediados del siglo VI hasta el siglo $\mathrm{V}$ a.e. incluido.

La escena que se representa es casi siempre la misma, si bien se introducen múltiples variantes en la composición y en el modo de realización de cada una de las piezas. El altar para el sacrificio de Heracles suele ocupar el centro de la imagen, como eje de la misma, aunque en algún caso, puede aparecer desplazado hacia un lateral o bien no estar presente. El modelo de altar es diferente en cada pieza. En torno a él aparece Busiris, bien sentado en él, desplomándose sobre él, caído delante del mismo... siendo atacado o habiéndolo sido por Heracles. Los sacerdotes, en la mayoría de las ocasiones, huyen atemorizados, constituyendo el altar el punto centrífugo. Otras veces aparecen echados por los suelos tras haber sufrido la ira heráclida, y en una minoría de ocasiones hacen frente al héroe heleno. Los sacerdotes, como tales, pueden llevar consigo cierto instrumental u objetos que intervendrían en el ritual del sacrificio de Heracles. Estos objetos, que no aparecen por igual en todas las cerámicas, son los siguientes: la machaira o cuchillo para efectuar la inmolación; el kanoun o cesto de tres esquinas; leña; instrumentos musicales (dobles auloi, que incluso aparecen con sus estuches y asociados a la phorbeia $^{17}$, liras y cítaras); recipientes cerámicos (generalmente hidrias e oinocoes, aunque también alguna crátera, y lo que parece ser algún lebes y un píxide); elementos como un martillo o carcajes; lo que asemeja ser una piel moteada; e incluso algún elemento mobiliario, como es el caso de una mesa. El carácter caótico de la escena por la huída de los sacerdotes se enfatiza en algunas ocasiones por los objetos, que aparecen caídos y abandonados por los suelos.

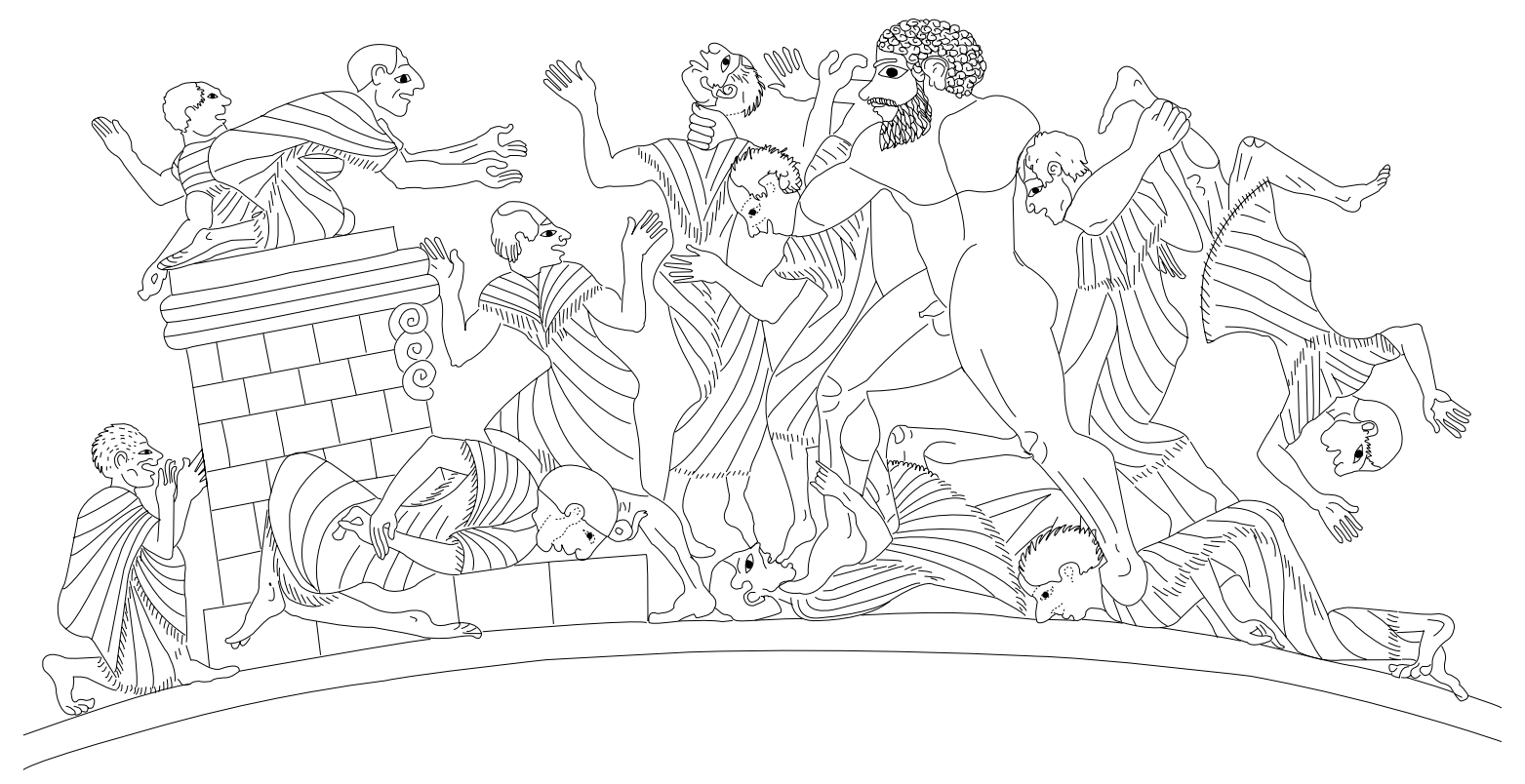

Figura 2. Heracles aniquilando a los egipcios. Hidria de figuras negras, ca. 530 a.e. Wien, Kunsthistorisches Museum 3576

17. Banda que se colocaba alrededor de la cabeza a la altura de las mejillas para controlar su inflamiento cuando se tocaba el doble aulos. 
En estas representaciones se pueden apreciar algunas cuestiones si diferenciamos las que están realizadas sobre pintura vascular de figuras negras respecto a la de figuras rojas. Las piezas de figuras negras son una minoría. En estas cerámicas Busiris está caracterizado en algunas ocasiones con el ureus, lo que lo diferencia del resto de personajes de la escena. Los urei son representados bien en la parte frontal de la cabeza del personaje, o a lo largo del cráneo, con o sin un enroscamiento del cuerpo de la serpiente que, cuando se representa con cuidado, puede ser simple o doble. En algún ejemplar se percibe cómo forma parte de una corona que posee un tratamiento superficial escamado ${ }^{18}$. Por otro lado, lo que es más importante es lo que podríamos considerar la plasmación de una diversidad étnica. Los sacerdotes y en general los personajes egipcios manifiestan una relativa diversidad en la tonalidad de su piel y en la coloración de sus barbas y cabellos, según el ejemplar analizado. Sin embargo, esta diversidad podría tratarse simplemente de un recurso artístico para evitar la monotonía. Esto sucede en una pieza ${ }^{19}$ en la que se emplea para singularizar diferentes tipos de jitones largos (por ser de colores diferentes, o con algún elemento decorativo o por ausencia del mismo). En otro ejemplar ${ }^{20}$, en una escena de caza en el registro inferior al episodio de Busiris ${ }^{21}$, dos de los canes aparecen en negro, mientras otro en blanco para resaltar frente el jabalí al que está atacando, pintado en negro. Además los cazadores que delimitan a ambos lados dicha escena se presentan como personajes antitéticos: uno de piel más clara y vestimenta oscura, y otro de piel oscura y ropajes más claros sin aparentes rasgos faciales diferenciadores. De esta forma, volviendo a la escena de Busiris, esto no tendría por qué atribuirse a un intento de diferenciar etnias sino, siguiendo lo anterior, podría tratarse del mismo recurso artístico. Destaca también en esta misma pieza ${ }^{22}$ (véanse figs. 3 y 4) la representación diferencial entre dos grupos de personajes. Frente a lo que podemos caracterizar como sacerdotes, hay otros individuos que parecen ser algún tipo de guardia personal armada que corre a socorrer al monarca en peligro. Las diferencias en la vestimenta son evidentes: los sacerdotes en kalasiris y los hombres armados en faldellín muy corto. Hay unos rasgos fenotípicos que los diferencian. El primer grupo posee un cierto alargamiento craneal y lo que parece un rasurado en la zona frontal del cráneo. En cuanto al segundo grupo, en la morfología nasal tal vez se enfatiza más el achatamiento, y está presente un considerable engrosamiento labial, y también pelo crespo o ensortijado.

Las representaciones de este segundo tipo aparecen sobre todo en la cerámica de figuras rojas, y comparativamente en muchos más ejemplares que respecto a las del primer grupo. Estas escenas han sido documentadas en su mayoría en cráteras de diferentes morfologías, además de en quílices, y en menor medida en hidrias, estamnos y peliques. La variabilidad de combinaciones entre las características con las que aparecen representados tanto Busiris como los sacerdotes egipcios nos ha llevado a hacer una aproximación estadística de la descripción de los rasgos que comparten tanto uno como los otros ${ }^{23}$. A continuación detallaremos cada uno de los elementos en los que hemos fijado nuestra atención.

18. Palermo, Museo Archeologico Regionale, 1986. (=LIMC III Pl. 131, Bousiris 29).

19. Cincinnati (OH), Art Museum, 1951.1 (=Beazley Archive 340563).

20. Wien, Kunsthistorisches Museum 3576 (= LIMC III, Pl. 128 Bousiris 9; LIMC I Pl. 323, Aithiopes 11).

21. Thesaurus cultus et rituum antiquorum (ThesCRA) (2004-2005): vol. III, lám. 44.

22. Véase nota 20. 

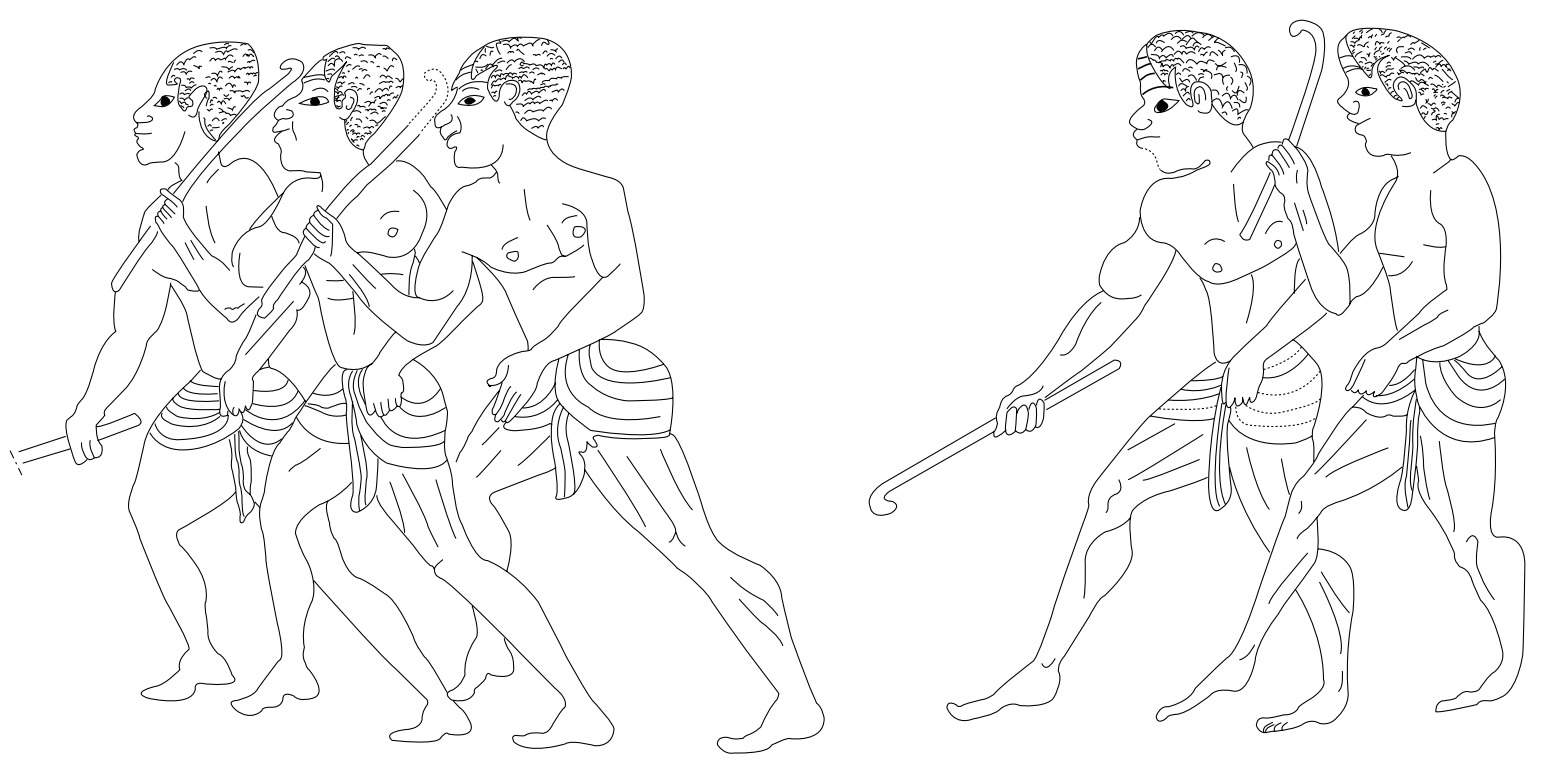

Figura 3. Grupo de guerreros o posible guardia personal de Busiris. Hidria de figuras negras, ca.530 a.e. Wien, Kunsthistorisches Museum 3576

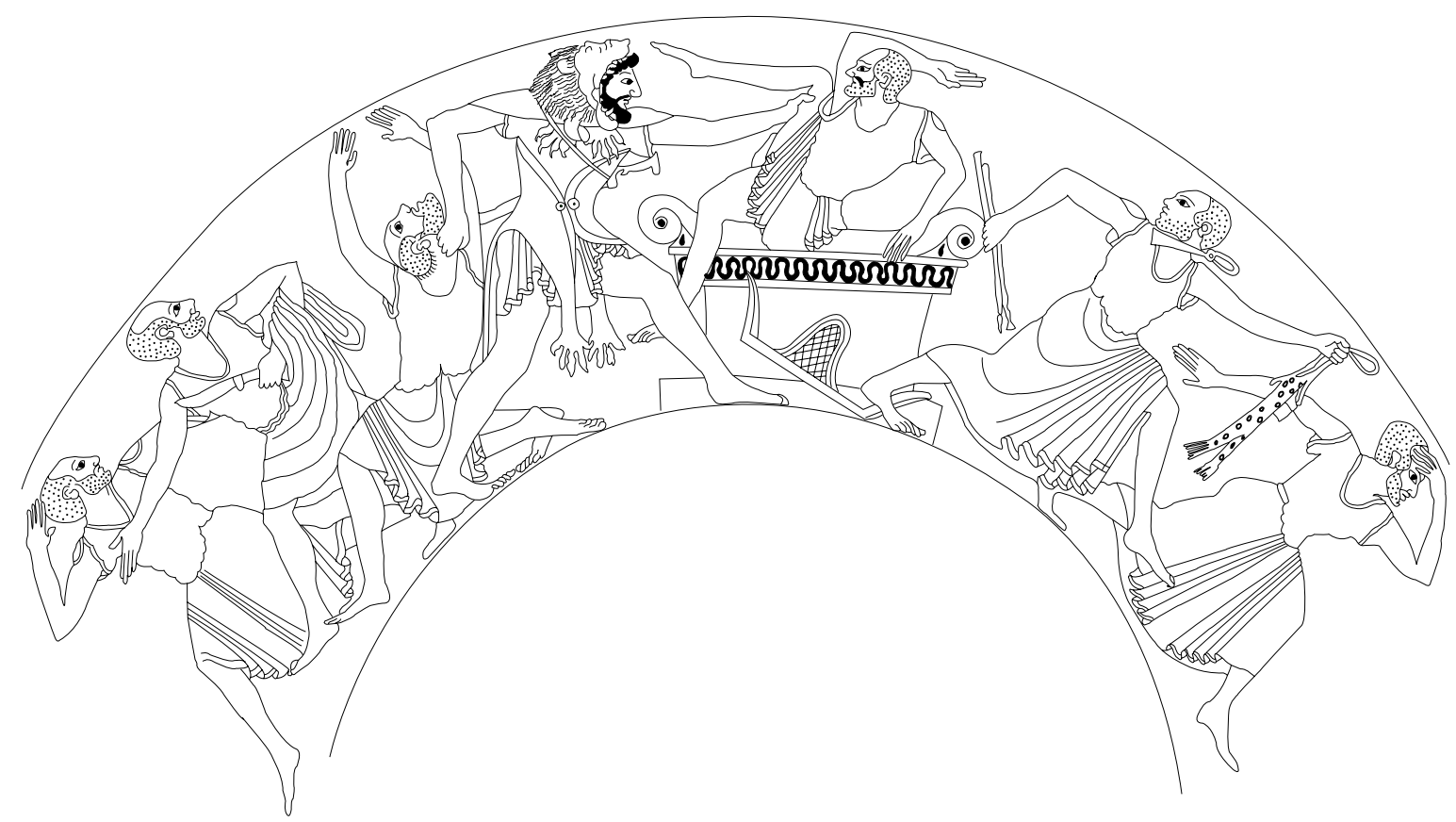

Figura 4. Lucha de Heracles con los egipcios. Quílice de figuras rojas, ca. 510 a.e. Roma, Museo Nazionale di Villa Giulia 57912 
a) El cabello: en el 20\% de las piezas (3) los sacerdotes y Busiris aparecen con el cráneo totalmente afeitado. En un 47\% (7) aproximadamente se les representa con afeitado parcial del cráneo de la zona correspondiente al hueso frontal (o tal vez se trate de una calva), y este afeitado se puede extender en mayor o menor medida a lo largo del mismo, llegando longitudinalmente incluso hasta la mitad del hueso parietal de un modo aproximado. El cabello dejado en los laterales y la zona posterior del mismo es representado en la mayoría de las ocasiones con un tamaño corto, y en menor medida como cabello emergente tras un proceso de rasurado. En un $33 \%$ (5), los personajes aparecen con pelo de un tamaño medio, y por tanto sin haber sido sometidos a ningún proceso de afeitado o rasurado. Asimismo hay algún que otro ejemplo en el que hay presentes en la misma pieza diferentes peinados de los ya mencionados.

b) La barba: en el $60 \%$ de las piezas (8), los personajes egipcios son representados todos ellos imberbes; en un 33\% (5) solamente algunos de ellos tienen barba, y sólo en un 13\% (2) la poseen todos. También hay que tener presente que en algunos de los personajes barbados, pero sólo en estos, aparece la presencia de bigote.

c) La morfología nasal: en la mitad de las representaciones se observa que hay cierto interés en acentuar la diferencia entre las narices de los personajes egipcios (incluido Busiris) con un cierto grado de achatamiento, y la de Heracles; en la otra mitad no se percibe diferencia alguna. Al mismo tiempo, hay incluso algún ejemplo en el que se observan disime- trías morfológicas entre los personajes egipcios.

d) El engrosamiento labial: aunque a veces es difícil de discernir, estimo que en un 53\% (7) de las representaciones existe, frente a un $40 \%$ en las que no. No obstante, la claridad de percepción de este rasgo en determinados personajes es mayor que en otros.

e) El prognatismo: la imprecisión para determinar con exactitud la presencia de esta característica fisiológica nos ha conducido a tener una actitud dubitativa con múltiples piezas. No obstante, el prognatismo está presente en un considerable número de las representaciones analizadas.

f) La morfología craneal: de ésta es destacable que en un $13 \%$ (2) aproximadamente, se observa un cierto alargamiento craneal en los personajes egipcios.

g) La vestimenta: hay una cierta diversidad, encontrándose en alguna de las piezas asimismo una variedad en la indumentaria en distintos personajes. En un 46\% (7) predominan los jitones cortos; en un 33\% (5), los jitones largos aunque también hay algunos que 1legan justo por debajo de la rodilla $(13 \%, 2)$; también están presentes los faldellines cortos $(13 \%)$.

h) Los complementos de adorno personal también se han tenido en cuenta: en un $46 \%$ (7) de las representaciones, los sacerdotes poseen una banda o cinta alrededor de la cabeza o del mismo modo están coronados con elementos vegetales; y sólo en una de las

23. El total de piezas cerámicas analizadas ronda la quincena. Por tanto, los problemas derivados de la conservación de la imagen pueden constituir un porcentaje relativamente considerable. También, la aparición de nuevos ejemplares puede hacer variar significativamente las conclusiones. 
piezas han aparecido los sacerdotes llevando pendientes, que eran circulares.

i) Podemos tener en cuenta además un rasgo que está presente en una de las piezas; la representación de miembros genitales circuncisos en los personajes egipcios ${ }^{24}$.

La variedad de representaciones de Busiris y los personajes egipcios propia de las piezas de figuras rojas la podríamos sintetizar del siguiente modo (fig. 4): rasurado en el área frontal del cráneo, imberbe, con una morfología nasal que puede diferenciarse o no de la de Heracles, cierto engrosamiento labial y en algunos casos prognatismo. Su indumentaria es el jitón corto, y no llevan ningún adorno personal. Debe tenerse en consideración asimismo que algunos de los rasgos que caracterizan a los personajes egipcios pudiesen estar exagerados y no se trataría sino de marcar una diferencia entre el personaje griego y los egipcios $^{25}$.

\subsection{Busiris en las fuentes literarias}

La imagen que aportan las fuentes literarias sobre Busiris es la que explicitaremos a continuación. Las referencias aluden a varias cuestiones muy bien diferenciadas. Podemos destacar aquellas asociadas a sus vínculos consanguíneos: "hijo de Poseidón y Lisianasa", "de noble origen", "hermano de Anteo"; así como las menciones que aluden al cargo que ocupaba como rey de Egipto o de los egipcios. Y por otro lado, aunque relacionado con lo anterior, se encuentran los apelativos. Los negativos son los que predominan de un modo considerable: se le califica de cruel $^{26}$, funesto ${ }^{27}$ y detestable ${ }^{28}$; y que ejerció un gobierno asociado a la tiranía ${ }^{29}$ y la impiedad $^{30}$. Todo esto está obviamente asociado al episodio mitológico, respecto al cual se alude cuando se explicita la sangre derramada en los altares y que consecuentemente mancillaba los templos. Isócrates ${ }^{31}$ deja entrever incluso la concepción por parte de algunos autores de que Busiris podría haber realizado prácticas antropofágicas tras los sacrificios de los extranjeros. Esta amalgama que conforma una descripción peyorativa creo además que puede enmarcarse en una tendencia más amplia que se manifiesta en la asociación de una variedad de características negativas a los egipcios ${ }^{32}$.

Los aspectos favorables a Busiris solamente los aporta Isócrates ${ }^{33}$. Éste de forma indirecta lo califica de inteligente y de "responsable del cuidado de la inteligencia". Esto debe comprenderse en el contexto en el que uno de los múltiples intereses de los helenos en la cultura egipcia fue su

24. Athènes, Musée Nacional A 9683 (=LIMC P1. 323 Aithiopes 13).

25. Siguiendo de nuevo a Annie-France Laurens, afirma que la mezcla y combinación de rasgos egipcios y etíopes se debería al limitado conocimiento que podrían tener los autores de las decoraciones pictóricas de las cerámicas acerca de los egipcios. Véase $L I M C$, III: 152.

26. "Saueior" (saeuus, -a, -um): Ou. Tr. III 11, 39.

27. "Triste" (tristis, -is, -e): Ou. Tr. III 11, 39.

28. “Inlaudati” (illaudātus, -a, -um): Macr. Sat. VI 7, 5. Servio Georg. III 5. Verg. G. III 5.

29. "Domino": Ou. Pont. III 6, 41-42. Tal vez no tiene por qué tener un carácter negativo como el que le aporta en su traducción José González Vázquez, 2001, Madrid: 418.

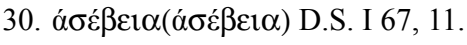

31. Isoc. Ep. XI 5.

32. Isaac, 2006: 352-370.

33. Isoc. Ep. XI 10-28. 
organización sociopolítica. Se constata una cierta predilección por parte de la intelectualidad griega por la institución monárquica, que era asociada a la estabilidad social. En este marco se inserta el Busiris de Isócrates. En dicha obra el monarca egipcio se presenta en una serie de biografías (entre ellas, las de Nicocles y Evágoras, reyes de Chipre) que tienen como objetivo enaltecer la monarquía ${ }^{34}$. Éste es el contexto de las afirmaciones isocráticas.

Por consiguiente y en resumen, en las fuentes literarias no se han documentado ningún rasgo o característica que pudiera ayudarnos a concebir físicamente a Busiris. Esto se debe a que la descripción física del monarca egipcio está subordinada al carácter negativo por el cual está inserto en los episodios heráclidas, donde Busiris y los sacerdotes adquieren y representan el papel de enemigos, sobre los cuales el héroe descargará su furia. Por tanto, la razón está, probablemente, en que los autores que aluden a Busiris consideran que los rasgos físicos no tienen relevancia entre aquellos factores que ellos quieren resaltar.

No obstante, se pudo haber aludido a las características físicas del personaje de una forma secundaria, pero quizás las diferencias físicas entre helenos y egipcios no fueran tan destacables como para hacer acto de presencia en la descripción del personaje. En cambio, el contraste físico mayor entre las poblaciones griegas y los personajes etíopes sí que motivan que se haga referencia a este aspecto, como posteriormente se verá.

\section{Memnón}

En la mitología clásica Memnón era considerado príncipe o rey de los etíopes. Fue hijo de Eos y Titonos, y sobrino de Príamo. Por esta razón de parentesco fue a luchar junto a él a Troya con un considerable ejército. En el campo de batalla combatió y mató a Antíloco. Luego Memnón intercambia unas airadas palabras con el padre de éste, Néstor, al lado del cuerpo inerte. La mala nueva es comunicada por el propio Néstor a Aquiles, quien al enterarse, rápidamente acude a vengar al compañero caído luchando contra Memnón. La lid entre ambos héroes fue observada por las divinidades entre las cuales se encontraban sus madres, Eos y Tetis. El combate se prolongó hasta que se inclinó la balanza en la psicostasia de Zeus, obteniendo la victoria Aquiles, y Memnón la muerte. Fueron los vientos los que recogieron al héroe caído y lo transportaron a un lugar ajeno al campo de batalla para ser visto por su madre. También se cuenta que fue Eos quien trasladó el cuerpo de su hijo hasta el lugar que sería su tumba ${ }^{35}$. Los compañeros de Memnón o las cenizas de su pira -según las versiones- fueron convertidos en las que se denominaron aves memnónidas, que acudían con una periodicidad anual ${ }^{36}$ a esta tumba, para conmemorar la muerte del héroe. Asociados al nombre de Memnón se hallarían varias construcciones ${ }^{37}$ : desde un camino público, hasta un supuesto palacio en Susa y/o su acrópolis, y otros hipotéticos palacios en Egipto (en Tebas y Abidos) y Etiopía. Entre estos últimos destacan

34. Gómez Espelosín y Pérez Largacha, 2003: 66-67.

35. Ael. $N A \mathrm{~V}, 1$. La tumba es ubicada en múltiples lugares: la Tróade (Ael. $N A \mathrm{~V}, 1$ ), Susa (Ael. $N A$ V, 1), Frigia Helespóntida (Str. XIII 1, 11; Hes. Fr. 353; Paus. X 31, 5-8.), Siria (Estrabón XV 3, 2.)... incluso llegando a afirmar su inexistencia (Philostr. Im. I 7.).

36. Ael. NA V 1; Hes. Fr. 343; Paus. X 31, 5-8; Plin. HN X 74.

37. Sobre el camino público véase: D. S. II, 22. Acerca de la acrópolis y/o supuesto palacio de Susa: D. S. II, 22 ; Str. XV 3, 2. Susa concebida como “ciudad de Memnón”: Hdt. V 54. Sobre el palacio etíope: D. S. II 22. En cuanto a palacios egipcios de Memnón: Str. XVII 1, 46 (en Tebas); Solin. 32, 41 (en Abidos). Las referencias a los colosos de Memnón son: Str. XVII 1, 46; Paus. I 42, 3. Otras citas acerca de estatuas relacionadas con Memnón (no explicitándose que se trate de los colosos de Memnón y otras): Tac. Ann. II 61; Callistr. I, 5; 9; Philostr. Im. I, 7; Philostr. Her. XXVI; VA VI, 4; Plin. HNXXXVI 58. 
las celebérrimas estatuas sedentes que flanqueaban la entrada al templo de millones de años de Amenhotep III, que son hoy conocidas como los colosos de Memnón.

\subsection{Memnón en la iconografía}

Las imágenes de Memnón en las decoraciones pictóricas cerámicas provienen principalmente de las producciones atenienses (tanto en piezas de figuras negras como rojas), aunque también se identifica su presencia en las corintias, calcídicas o campanienses. Se pueden circunscribir a un período que va desde los años 80-70 del siglo VI a.e. hasta mediados del siglo $\mathrm{V}$ a.e., aunque se ha documentado, ya de forma más aislada, alguna pieza más tardía, del siglo IV (c. 340-330 a.e.).

He establecido cuatro tipos de escenas en las que aparece este héroe, siguiendo en cierta medida el $L I M C^{38}$. Éstas son la despedida de Memnón en casa de sus padres antes de partir al campo de batalla; él acompañado de una comitiva de guerreros etíopes; de su combate con Aquiles; y por último, la recogida y transporte de su cadáver siendo recogido y transportado bien por su madre Eos o bien por sus soldados.

\subsubsection{Primer Tipo: Despedida de Memnón de sus padres}

El primer tipo de escena muestra una escena

[ 98 ] en la que el héroe se despide de sus progenitores (fig. 5). Es la menos representada, sólo documentada en tres piezas. Se trata de vasos de figuras rojas de producción ática, y que se asocian a una cronología de la década de los años sesenta del siglo $\mathrm{V}$ a.e., o de manera más genérica, a la primera mitad de esa centuria. El tipo de piezas cerámicas en las que se ha documentado son: un quílice, un estamnos y una crátera de volutas. En el ejemplar examinado, Memnón aparece con armadura, escudo circular y lanza, ante Eos y un sedente Titonos, que sostiene un bastón con la mano derecha. Tanto el padre como el hijo aparecen barbados y sin ningún rasgo fenotípico que pueda adscribir a Memnón con la población etíope.

\subsubsection{Segundo tipo: Memnón y la comitiva de guerreros}

El segundo tipo de imagen es en la que aparece el héroe acompañado de una escolta de soldados (fig. 6). Está plasmado en piezas de figuras negras y de figuras rojas áticas con una cronología que va desde el 540 al 500 a.e. de un modo aproximado. Sólo se han documentado en ánforas. El monarca etíope aparece vestido con armadura (grebas, yelmo...) y protegido con escudo circular y una o varias lanzas; se encuentra flanqueado por dos guerreros que están girados hacia él. Estos soldados van vestidos con armaduras y, según las distintas representaciones, portan mazas, arcos, carcajes, espadas y algún escudo que aparenta ser elíptico. En algunas ocasiones también puede aparecer un perro junto al héroe. Este tipo de escena es sumamente importante para nuestra investigación ya que podríamos establecer rasgos de diferenciación o de semejanza de Memnón respecto a la población sobre la que gobierna. No obstante, lleva puesta una armadura, de la cual forma parte el yelmo. Éste oculta la forma del cabello y dificulta valorar cuestiones que podrían estar presentes, tales como el engrosamiento labial y la morfología nasal. Sin embargo, en alguna escena aparece el yelmo ligeramente levantado, lo que nos permite inferir que de nuevo Memnón está representado con rasgos físicos que no se diferencian respecto a los helenos. La morfología nasal de sus acom- 


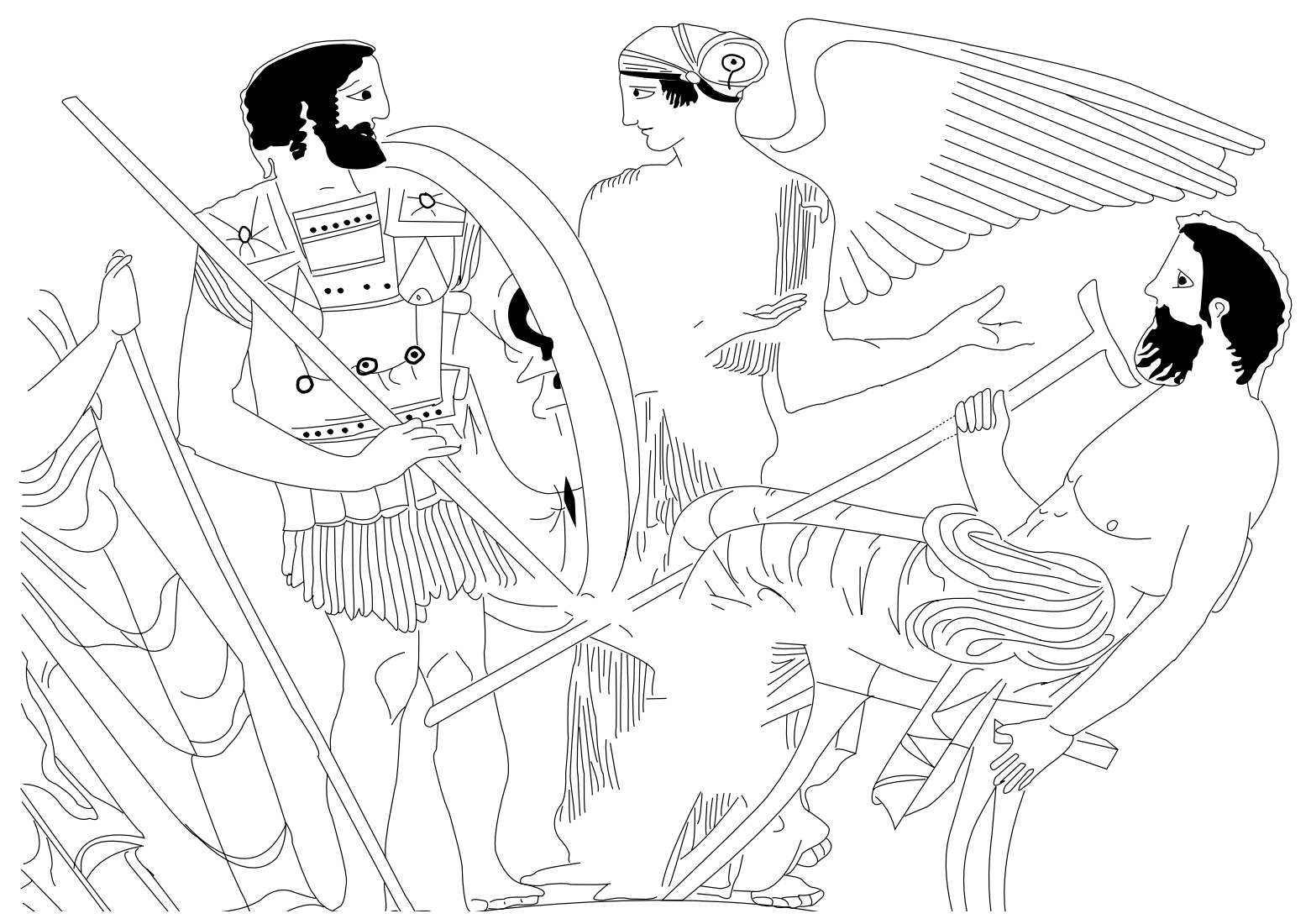

Figura 5. Memnón ante sus padres, Eos y Titonos. Quilice de figuras rojas, ca. 460-50 a.e. Freiburg im Breisgau, Morat-Institut für Kunst und Kunstwissenschaft

pañantes es claramente diferente. Estos tienen su nariz chata, frente a la del héroe, considerablemente alargada. Además, poseen pelo crespo o ensortijado. En algunas representaciones el monarca etíope aparece con una mayor altura respecto a ellos, aunque pueda simplemente tratarse del empleo del recurso artístico de la perspectiva simbólica, que consiste en dar mayor tamaño a los personajes más relevantes. En numerosas ocasiones Memnón aparece con largos cabellos y barbado, frente a sus camaradas de pelo corto $\mathrm{y}$, frecuentemente, imberbes. Esto nos lleva a considerar que tal vez se trate de una comitiva compuesta por individuos negroides pertenecientes al ejército etíope dirigido por el héroe. Dicho ejército es el que documentamos en las fuentes literarias ${ }^{39}$.

\subsubsection{Tercer tipo: Lid entre Aquiles y Memnón}

El tercer modelo de escena es la lucha contra Aquiles en el campo de batalla (fig. 7). Es la más frecuente. Se documenta mayoritariamente en piezas de figuras negras, aunque también está presente en un número considerable de cerámicas de figuras rojas. Estas escenas suele predominar 


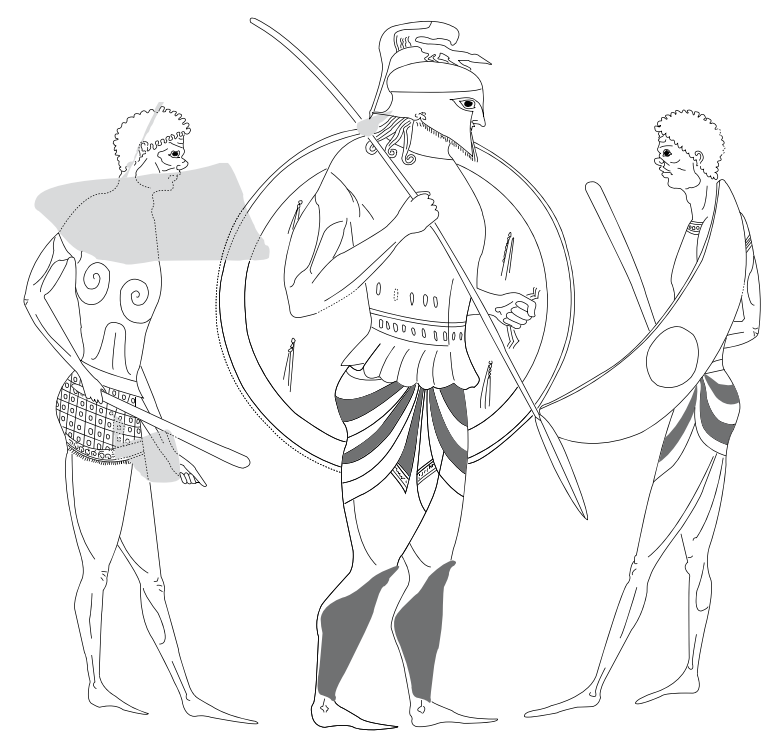

Figura 6. Memnón y su comitiva de guerreros. Ánfora de figuras negras, ca. 550-25 a.e. London, British Museum 1849.5-18.10

sobre todo en ánforas y de mayor a menor relevancia, también en quílices, cráteras y lécitos, y también se encuentran en otra multitud de piezas de forma mucho menos frecuente. Además, es el tipo de imagen de Memnón que aparece más tempranamente, a partir del 580 a.e., y se discute si existía en tiempos más remotos ante la ausencia de evidencias consistentes. La escena tiene múltiples variantes. Los héroes pueden luchar solos o acompañados. Puede estar presente $u$ omitirse a Antíloco, al que acababa de matar Memnón, en el suelo, bien con su armadura o despojado de ella al ser vencido en el combate. De forma habitual sue- algunas escenas en las que ambos guerreros pelean en lo que parece un combate en condiciones de equidad, en otras ya Memnón es representado cuando acaba de ser herido, en el momento en que está cayendo al suelo. También es frecuente que la escena esté acompañada de otras ${ }^{40}$.

En cuanto a la descripción de los héroes, ambos, como es propio del contexto, van protegidos con armaduras -aunque también hay representaciones en las que ambos guerreros luchan desnudos-, grebas y yelmos y llevan lanzas y/o espadas y escudos. La similitud entre los personajes es en numerosos casos total. Las diferencias podrían observarse en ligeras variaciones en las corazas, en los yelmos o en los escudos (circulares o beocios, es decir, ovales con dos escotaduras semicirculares paralelas en los bordes). En algunos ejemplos la única diferencia fisonómica reside en que Memnón puede aparecer barbado frente a un imberbe Aquiles. Todo apunta a que Memnón no es concebido en sus características físicas de un modo distinto a un heleno.

En las cerámicas de figuras negras se acentúa más el dimorfismo sexual en la coloración de la piel frente a las disimetrías étnicas, como ocurre en las representaciones egipcias. Esto se percibe en la diferente coloración de la piel de las madres de sendos héroes, que por ser mujeres tienen una pigmentación en la cerámica mucho más clara que sus hijos, que son varones. Sin embargo y como hemos afirmado anteriormente, la caracterización física de Memnón es similar o igual a la de cualquier personaje heleno y no se observan desigualdades destacables en su fisonomía.

La lucha entre ambos guerreros no fue solamente plasmada en la decoración cerámica, sino

40. Por un lado, uno o varios frisos de animales y/o fauna mitológica, destacando las esfinges y las sirenas. Entre los animales se pueden destacar panteras, leones, carneros, cisnes, gallos, e incluso algún toro o un jabalí. Por otro, también se observan sátiros y ménades danzando alrededor de un Dionisos que lleva un cuerno. Y por último, escenas en las que aparecen guerreros y jinetes. 


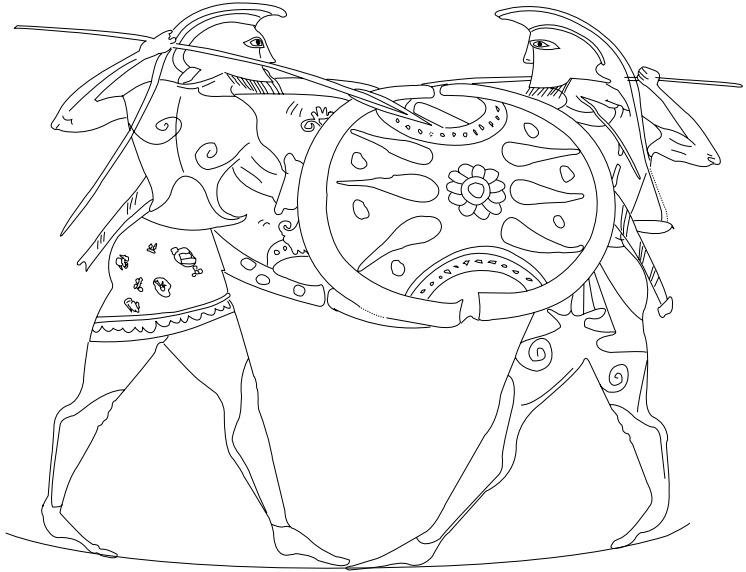

Figura 7. Lid entre Aquiles y Memnón. Ánfora de figuras negras, ca. 520-10 a.e. Città del Vaticano, Musei Vaticani 16591 (389)

que ha llegado hasta nosotros a través de otro tipo de fuentes, como es el friso oriental del tesoro de los sifnios en Delfos. Sin embargo, desde nuestro punto de vista actual no creemos que aporte nada novedoso para nuestra investigación frente a lo ya afirmado.

\subsubsection{Cuarto tipo: El cadáver de Memnón}

El cuarto tipo de escena muestra a Memnón muerto tras perder su pugna contra Aquiles (fig. 8). Abunda en la cerámica ática de figuras negras, aunque también está presente en piezas de figuras rojas, y en otras realizadas con el procedimiento decorativo denominado sixtechnique. El carácter fúnebre de la imagen se relaciona directamente con el tipo de piezas en las que se plasma. Estas son en un modo muy mayoritario, lécitos, recipientes funerarios por excelencia, aunque también se han documentado en cráteras, quílices y ánforas, y aún más escasamente en escifos, olpes, peliques, y en algún epínetron. La representación de esta escena tiene unas cuantas variantes. Lo más usual es que aparezca Eos lamentándose ante el cadáver de su hijo o en actitud de aprehensión del cuerpo y transporte del mismo. En algunos ejemplos están presentes además Hipnos y Thanatos, que son en este caso quienes llevan el cuerpo inerte del héroe caído en el campo de batalla. La segunda variante la constituye una minoría de ejemplos, en los que el cuerpo de Memnón es recogido por individuos etíopes, miembros del ejército al que dirigía el propio Memnón ${ }^{41}$.

La importancia de este tipo de escenas es que Memnón, como guerrero vencido, ha sido despojado de su armadura, lo que nos permite observar aquellos rasgos que antes quedaban ocultos. De manera genérica se le muestra desnudo; sólo en algunas piezas aparece con armadura. Suele llevar un cabello de longitud media o larga, y es habitual que muestre barba y bigote. En muy pocas aparece con una cinta en la cabeza, y también en otras, con algún resto de la vestimenta o el armamento que llevaba mientras luchaba, como el yelmo o una espada. En lo que respecta a los rasgos fenotípicos no hay indicios de una plasmación de una diferenciación étnica.

El episodio mitológico del cuerpo de Memnón siendo llevado por Eos también se ha documentado en espejos grabados. Sin embargo, en los que hemos analizado hasta el momento ${ }^{42}$, no existen variaciones significativas que contradigan lo anteriormente expuesto o aporten información adicional sobre la cuestión.

41. Se ha constatado la existencia de este tipo de escena aunque no hemos podido acceder a ninguna representación de la misma, por lo que únicamente mencionamos su existencia sin la posibilidad de analizarla iconológicamente como hubiéramos pretendido.

42. Se han analizado varios ejemplares, aunque su estudio particular queda fuera del objetivo de este trabajo. Son espejos que han sido datados en el siglo $\mathrm{V}$ a.e., c. 470-450 a.e., y por tanto cronológicamente contemporáneos a algunas representaciones del mismo tipo. Véase LIMC III: 458. 


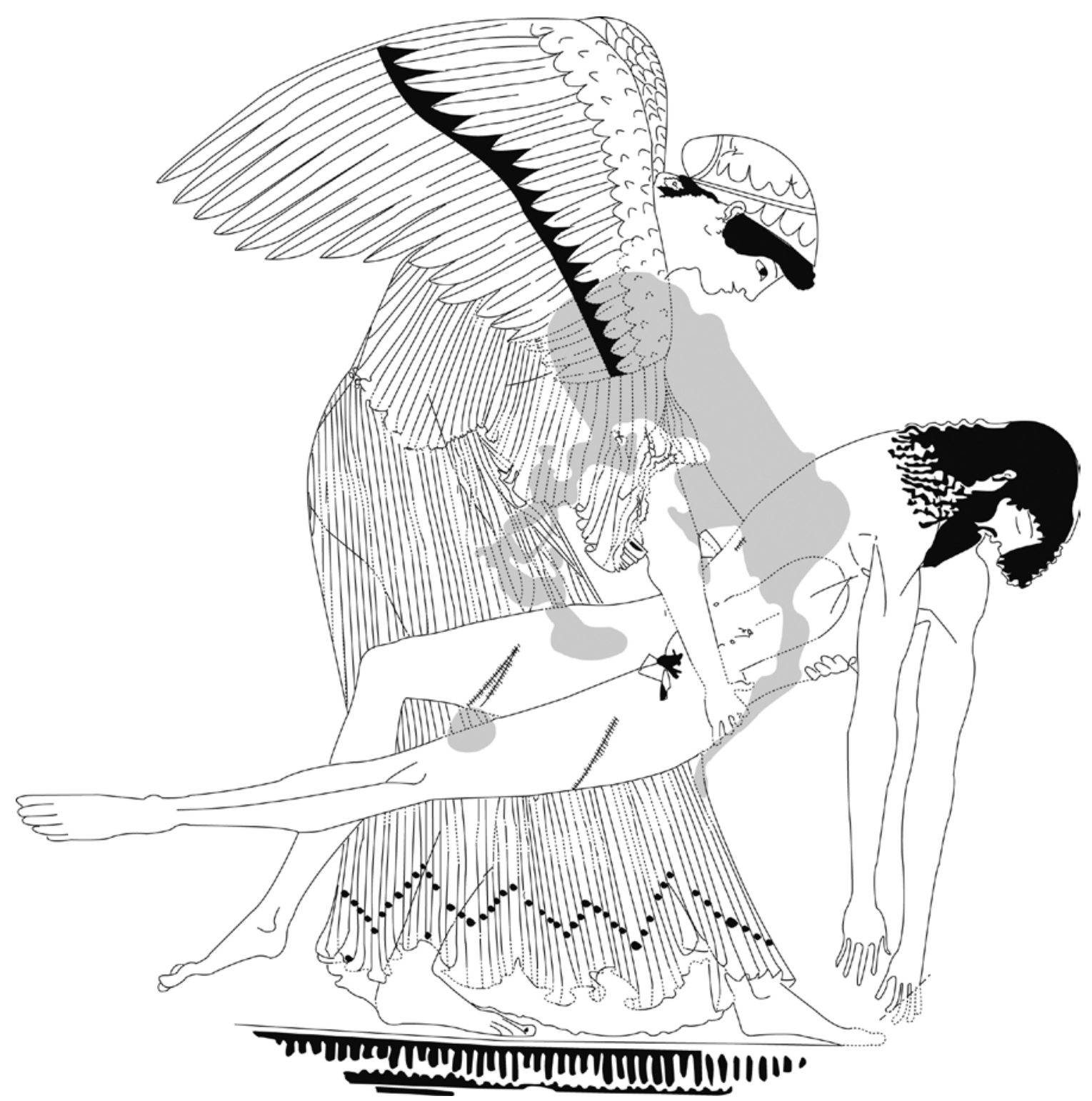

[102]

Figura 8. Eos portando el cuerpo inerte de su hijo Memnón. Quilice de figuras rojas, ca. 460-50 a.e. Paris, Louvre G 115

\subsection{Memnón en las fuentes literarias}

Las fuentes literarias nos muestran un retrato de Memnón de mucho interés, como en seguida explicitaremos. A grandes rasgos los calificativos que se asocian a su figura pueden catalogarse según el contexto al que hagan referencia. Pode- mos citar las alusiones de Memnón como "hijo ${ }^{43}$ (de Titonos y) de Eos", o de la Aurora o Erigenía como era también denominada. También se explicita su "origen ${ }^{44}$ divino" y algunas otras referencias a su parentesco ("primo de Héleno"45, e indirectamente se menciona que era primo de Paris $^{46}$ ). Los calificativos que se explicitan están 
vinculados a su función sociopolítica ${ }^{47}$ de dirigente de los etíopes: "príncipe", "rey", "caudi1lo", "soberano" o jefe del ejército etíope. Debemos referirnos también a aquellos apelativos empleados en un contexto bélico y que describen a Memnón como guerrero ${ }^{48}$. De esta forma, se ensalza su valentía y nobleza de espíritu, su fuerza, su intrepidez, su virilidad, su poderoso ánimo, y se le designa entre otros calificativos como "belicoso", "perínclito", “ávido”, "poderoso", "guerrero divino", "asesino de hombres", "terrible", "despiadado asesino de hijos", "del todo igual al impetuoso Ares", etc. Sin embargo, tenemos que destacar que en las descripciones que han podido ser documentadas de Memnón, las menciones a sus características físicas son relativamente escasas: Filóstrato y Pausanias ${ }^{49}$. El primero alude a la extensión y por tanto al gran tamaño del héroe, y también a la longitud de sus cabellos, fijándose en sus rizos. Ambos autores lo describen como barbado, aunque Filóstrato deja claro que su barba es juvenil ${ }^{50}$. Pero lo que llama nuestra atención es que diversos autores a partir del siglo I a.e. lo califican mediante una referencia a su coloración dérmica, utilizando los adjetivos: melas $^{51}(\mu \varepsilon \dot{\lambda} \alpha \varsigma)$ y niger ${ }^{52}$. Como afirma Snowden ${ }^{53}$, estos términos que pueden traducirse como negro y oscuro respectivamente, eran usados entre otros vocablos por griegos y romanos para describir a poblaciones con una tonalidad de piel más oscura que la suya. Se ha estudiado asimismo que dichos términos están insertos en una gradación terminológica a la hora de calificar a dichas poblaciones. Melas significa negro, mientras que niger significa oscuro y además, negro, o un color que se aproxima a este. Ovidio también nos aporta cierta información con el empleo del recurso literario de la antítesis. De esta forma declara: “...creería que los cisnes son del color de Memnón. Pero ni la leche se cambia en negra pez, ni se convierte en terebinto lo que era marfil de brillante blancura..." ${ }^{54}$. Filóstrato nos caracteriza al personaje con un rostro negro intenso, y curiosamente al hacer referencia a uno de los colosos de Memnón lo califica como ela-

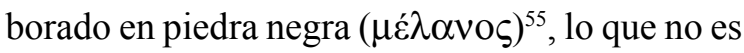
cierto. Un ejemplo similar se encuentra en Sexto Pompeyo Festo un autor prácticamente contemporáneo al anterior (siglo II d.e.). En su obra $D e$ Verborum Significatione afirma que en el Comicio de Roma hay una piedra negra (niger lapis) que refleja un lugar funesto asociado a la muerte de Rómulo ${ }^{56}$, y vinculado asimismo a un santuario de Vulcano. Dicha piedra fue documentada

43. Philostr. Im. I 7, 1; VA VI 4. Manil. I 767. Pi. N. VI 49-54. Q.S. II 235-239; 495; 500; 554; 569; $595 ; 610$.

44. Q. S. II 418.

45. Pi. N. III 62 ss.

46. D. Chr. XI 50.

47. D. Chr. XI 116-117. Philostr. Im. II 7, 4. Hes. Th. 985. Ou. Pont. I 4, 57-58. Pi. I. V 41; P. VI 31. Q. S. II 101; 204; $570 ; 584 ; 630 ; 647 ; 656$.

48. D.S. II 22. Philostr. Im. I 7, 2; II 7,4. Pi. I. V, 41; VIII 54; P. 31. Q.S. II 31; 44-45; 100; 202-204; 280; 322-323; 326; $375 ; 379 ; 387 ; 418 ; 569$.

49. Philostr. Im. I 7, 2. Paus. X 31, 5-6.

50. Aunque haciendo mención a una de las estatuas de las conocidas como colosos de Memnón, lo califica de imberbe: Philostr. VA VI 4.

51. Philostr. Im. I 7, 2; II 7, 2.

52. Manil. Astronomica I 767. Ou. Am. I 8, 3. Verg. Aen. I 489.

53. Snowden, 1996: 113.

54. Ou. Pont. 95-98. Traducción de José González Vázquez. En la versión latina: “...Memnonio cygnos esse colore putem. Sed neque mutatur nigra pice lacteus umor, nec quod erat candens fit terebinthus ebur." (Les Belles Lettres, 1977).

55. Philostr. V. A. VI, 4. De esta similitud también se ha percatado Anneliesse Kossatz-Deissmann (LIMC VI: 461) 
arqueológicamente y tampoco era de tal color ${ }^{57}$. Estamos por tanto ante el simbolismo cromático aplicado a dos elementos pétreos diferentes en el mismo contexto cultural: el negro de los colosos porque aludía claramente a la coloración dérmica que debería tener el personaje representado, y la piedra del Comicio romano porque está asociada con el negro, un color que las sociedades clásicas asociaban a las divinidades ctónicas como Vulcano, pero también entre otros elementos a la muerte, en este caso de Rómulo ${ }^{58}$.

Cuatro o cinco siglos antes, Píndaro ya había calificado a Memnón de "etíope”. Pero, ¿era éste un mero gentilicio vinculado a un monarca etíope de rasgos físicos extranjeros o lo caracterizaba físicamente como tal? No debe olvidarse que etíope (Aí⿴ío\%) significa literalmente "cara quemada" en alusión al color de piel de las poblaciones a las que se hacía referencia con dicho apelativo $^{59}$. Con todo, en las representaciones cerámicas coetáneas de Memnón no hay como hemos analizado anteriormente, ningún rasgo fenotípico que nos pueda inducir a que era caracterizado físicamente como negroide. Por tanto, lo más seguro sería que Píndaro lo utilizase como un mero gentilicio, o que hubiesen distintas adscripciones étnicas sincrónicas en este momento para el personaje. Sería posteriormente Diodoro de Sicilia ${ }^{60}$ quien consideraría la posibilidad de que Memnón, según la opinión de los propios etíopes, fuese originario o autóctono del país de éstos, considerándolo de rasgos similares a los de ellos mismos.

Por consiguiente podemos afirmar que la concepción étnica de Memnón sufrió una modifica- ción considerable. Las representaciones cerámicas de los siglos VI, V y IV a.e. lo caracterizan como un individuo que físicamente es igual o muy semejante a los griegos. De este modo se destaca su ascendencia familiar frente a su consideración de monarca etíope. No obstante, en un momento que pudiese estar entre finales del siglo IV y el siglo I a.e., el personaje se ve modificado. Es en este período en el que Memnón se comienza a concebir como un etíope con rasgos negroides, recalcando por tanto su consideración étnica frente al factor familiar anteriormente explicitado.

\section{Conclusiones}

En conclusión (cuadros 1 y 2), el presente trabajo ha tenido como objetivo analizar cómo eran concebidos Busiris y Memnón en unos tipos concretos de fuentes clásicas. Hemos explicado cómo las fuentes literarias no hacen ningún tipo de referencia a las características físicas de Busiris. Como ya se ha afirmado, las causas de esto podrían ser: bien que las alusiones de $\mathrm{Bu}-$ siris acentúan de manera prioritaria su conducta inserta en el contexto mitológico del episodio heráclida o bien que los rasgos físicos de Busiris no se diferencian tanto de las poblaciones helenas como para llamar su atención de modo preferencial, al igual que ocurre con la práctica totalidad de las referencias a personajes egipcios en la mitología griega ${ }^{61}$. Como plantea Snowden, en general las cuestiones étnicas eran aplicadas en la Antigüedad a personas de marcadas características negroides y sólo ocasionalmente a mulatos y a personas de extracción mestiza ${ }^{62}$. Frente a

56. Fest. 177.32-34.

57. Cornell, 1999: 122-123.

58. Snowden, 1991: 82.

59. LIMC I: 413. Snowden, 1996: 113.

60. D. S. II 22, 4.

61. Véase nota 3. 
esto Memnón, caracterizado como etíope, sí que logra obtener un mayor interés en algunos autores, que explicitan la relevante diferenciación física entre ellos, como individuos pertenecientes a las sociedades grecolatinas, y el héroe. Ya en los siglos VI-V a.e. Píndaro lo califica de etíope, aunque paralelamente es representado como un griego en las cerámicas helénicas. Por lo tanto estamos ante varias concepciones paralelas del personaje o que el apelativo que le aplica a Píndaro sea simplemente un gentilicio, sin las connotaciones étnicas que implicarían el término en griego $^{63}$. Es sólo a partir del siglo I a.e. cuando se le comienza a asociar con los términos melas ( $\mu \varepsilon \dot{\lambda} \alpha \varsigma)$ y niger.

En las representaciones cerámicas se observan múltiples cuestiones. En las áticas de los siglos VI y $\mathrm{V}$ a.e., percibimos una cierta diversidad coetánea en el modo en el que se plasman los rasgos fenotípicos de Busiris y los sacerdotes. Se incide principalmente en estas características físicas como elementos diferenciadores. En cambio, en las piezas centromediterráneas del siglo IV a.e. se prima la relación del monarca egipcio con un modo de representación que pudiéramos considerar orientalizante. Adicionalmente, y de manera genérica, debe tenerse en cuenta que en este tipo de fuentes los rasgos físicos pudiesen estar exagerados para un mejor contraste en una típica dualidad representativa bárbaros - helenos -. Por otro lado, Memnón es representado siempre como un heleno. De este modo, analizando conjuntamente los distintos tipos de fuentes podemos afirmar que Memnón constituye un ejemplo de cómo cambia la concepción étnica de un personaje mitológico. En los siglos VI-V y IV a.e. era caracterizado como un heleno más. Se enfatizaba más su ascendencia familiar a que fuese monarca de los etíopes. No obstante, ya a partir del siglo I a.e. se le caracteriza físicamente como un etíope, primando la etnicidad del lugar sobre el que gobierna frente a sus antepasados. Por consiguiente y de manera genérica, se produce una transformación en la concepción de Memnón entre el siglo IV a.e. y el siglo I a.e.

Por último, debemos destacar que el presente trabajo también ha dejado entrever la caracterización física diferencial de varios conjuntos de personajes, asociados tal vez a ambientes socioprofesionales y/o a grupos étnicos distintos. Los personajes mitológicos individualizados, es decir, tanto Busiris como Memnón aparecen en determinados momentos o contextos como carentes de rasgos físicos diferenciadores a los helenos, que tal vez pudiese responder a su entidad como héroes o personajes míticos. Por otro lado, la comitiva de guerreros de Memnón y el séquito militar de Busiris (éste se representa en una pieza específica) tienen marcados rasgos negroides que corresponde a una concepción helena sustentada por un conocimiento empírico de soldados mercenarios con estas características en Grecia.

Pero, ¿estamos ante personajes estereotipados, es decir, de construcciones más o menos aleatorias insertando varias características físicas que los definen claramente? Snowden asocia la amplia difusión de representaciones de individuos de rasgos negroides en el mundo clásico con un conocimiento profundo de personas con tales rasgos, y que fueron utilizados como modelos reales. Es decir, que los artistas clásicos no se limitaron a realizar repeticiones de unos tipos convencionales de personas con caracteres negroides, sino que podrían poseer un conocimiento de primera mano de la gente que repre$\operatorname{sentaban}^{64}$.

62. Snowden, 1991: 65.

63. Como se ha explicado antes, AíOío $\psi$ quiere decir en griego "cara quemada".

64. Snowden, 1991: 15-16. 
Me planteo en qué medida puede ser aplicable esto a los egipcios, ya que en las escenas donde aparecen se aprecia un abanico de caracterizaciones físicas. La sociedad egipcia antigua era profundamente heterogénea, y más todavía en el momento en el que se contextualizan las fuentes que he utilizado, y en el que se desarrollan y se plasman en la iconografía los mitos que tratamos aquí. Pero también es muy arriesgado y discutible desde mi punto de vista considerar que plasmaban exactamente aquello que veían. No obstante, creo que las sociedades clásicas representan disimetrías físicas en los egipcios ya sea por conocimiento o ignorancia de tal población, aunque me inclino por pensar en la primera opción, por los contactos establecidos durante siglos. También las sociedades grecorromanas observan diferencias físicas entre los egipcios y aquellas poblaciones que en las fuentes literarias denominan etíopes, con unos rasgos físicos marcadamente negroides.

En suma, el estudio iconológico de las fuentes cerámicas helénicas, a pesar de no estar exentas de problemas, nos aporta una perspectiva distinta en la investigación de la caracterización étnica de sociedades antiguas como la egipcia.

\section{Busiris}

Cuadro 1

\begin{tabular}{l|l|l}
$\begin{array}{l}\text { Busiris } \\
\text { Fuentes literarias }\end{array}$ & Fuentes iconológicas \\
\hline \multirow{4}{*}{$\begin{array}{l}\text { No referencias a características } \\
\text { físicas }\end{array}$} & ss. VI-V a.e. (áticas) & $\begin{array}{l}\text { Diversidad coetánea de } \\
\text { representación Busiris - } \\
\text { sacerdotes }\end{array}$ \\
\cline { 2 - 3 } & Destacan rasgos fenotípicos \\
\cline { 2 - 3 } & s. IV a.e. (centromediterráneas) & $\begin{array}{l}\text { Se vincula con tipo de } \\
\text { representación orientalizante }\end{array}$ \\
\cline { 2 - 3 } & $\begin{array}{l}\text { Posibilidad de exageración para contrastar rasgos físicos } \\
\text { Bárbaros - helenos }\end{array}$
\end{tabular}

[ 106] Memnón

Cuadro 2

Fuentes literarias

Fuentes iconológicas

\begin{tabular}{l|l|l}
\hline \multicolumn{2}{l|}{ Sí hay referencias a características físicas } & \multirow{2}{*}{ Aparece como un heleno } \\
\cline { 1 - 2 } ss. VI-V a.e. & Píndaro lo califica de "etíope" &
\end{tabular}




\section{Bibliografía}

Alvar EzQuerra, J. (DIr.)

2000 Diccionario Espasa de Mitología Universal. Madrid.

BARD, K. A.

1996 Ancient Egyptians and the Issue of Race, en Lefkowitz, M. R. y MacLean Rogers, G. (eds.): Black Athena Revisited, Chapel Hill: 103-111.

BÉRARD, C.

2000 The Image of the Other and the Foreign Hero, en Cohen, B. (ed.): Not the Classical Ideal: Athens and the Construction of the Other in Greek Art: 390-412.

Bernal, M.

1993 [1987] Atenea Negra: las raíces afroasiáticas de la civilización clásica. Vol I. La Invención de la Antigua Grecia, 1785-1985. Barcelona.

Brace, C. L.; Tracer, David P.; Yaroch, L. A.; RobB, J.; Brandt, K; Nelson, A. R.

1996 Clines and Clusters versus « Race ». A Test in Ancient Egypt and the case of a death on the Nile, en Lefkowitz, M. R. y MacLean Rogers, G. (eds.): Black Athena Revisited, Chapel Hill: 129-164.

Carpenter, T. H.

2001 [1991] Arte y Mito en la Antigua Grecia. Barcelona.

Cervelló Autuori, J.

1996 Egipto y África. Origen de la civilización y la monarquía faraónicas en su contexto africano. Barcelona.

CoRnell, T. J. 1999 [1995] Los Orígenes de Roma c. 1000-264 a.C. Italia y Roma de la Edad del Bronce a las guerras púnicas. Barcelona.
FAtÁs, G.; Borrás, G. M.

2001 Diccionario de términos de Arte y elementos de Arqueología, Heráldica y Numismática. Madrid.

Fauvelle-Aymar, F.-X. ; Chrétien, J.-P.; Pe-

RROT, C.-H.

2000 Afrocentrismes. L'histoire des Africains entre Égypte et Amérique. Paris.

Goldhill, S.; Osborne, R. (EDs.)

1994 Art and Text in Ancient Greek Culture. Cambridge - New York.

Gómez Espelosín, F.J.; Pérez Largacha, A.

1997 Egiptomanía. El mito de Egipto de los griegos a nosotros. Madrid.

IsAAC, B. H.

2006 The invention of racism in classical antiquity. Princeton (New Yersey) Woodstock (Oxtordshire).

KuRTZ, D.

1997 The Beazley Archive [en línea]: $<$ ht t p:// www.cvaonline.org/ BeazleyAdmin/Script2/default.htm> [Consulta: noviembre-diciembre 2005 y enero 2006].

Lefkowitz, M. R.; MacLean Rogers, G. (eds.)

1996 Black Athena Revisited. Chapel Hill.

LEXICON ICONOGRAPHICUM MYTHOLOGIAE

CLASSICAE

1981-1999 (LIMC). Zürich - München.

Miller, M. C.

2000 The Myth of Bousiris: Ethnicity and Art, en Cohen, B. (ed.): Not the Classical Ideal: Athens and the Construction of the Other in Greek Art, Leiden / Boston / Köln: 413442. 
Paulys Realencyclopädie der Klassischen AltertermswissensChaft

1893- Stuttgart.

Petrie, W. M. F.

1974a [1896] Naqada and Ballas. Warminster, Wiltshire (England) - Encino, California.

1974b [1920-1921] Prehistoric Egypt. Corpus of Prehistoric Pottery and Palettes. Warminster, Wiltshire (England) - Encino, California.

Roth, A. M.

2001 Afrocentrism, en Redford, D. B. (ed.): The Oxford Encyclopedia of Ancient Egypt, Oxford: vol. I, 29-32.

SCHAUENBURG, K.

1974 Achilleus als Barbar; ein antikes Mißverständnis, Antike und Abendland 20: 88-102.
SMITH, S. T.

2001 Race, en Redford, D. B. (ed.): The Oxford Encyclopedia of Ancient Egypt, Oxford: vol. III, 111-116.

SNOWDEN JR., F. M.

1991 [1983] Before Color Prejudice. The Ancient View of Blacks. Cambridge (Massachusetts) - London.

1996 Bernal's «Blacks» and the Afrocentrists, en Lefkowitz, M. R. y MacLean Rogers, G. (eds.): Black Athena Revisited, Chapel Hill: 112-128.

Thesaurus CUltus ET RITUUM ANTIQUORUM

(ThesCRA)

2004-2005 Los Angeles. 


\section{Trabajos de Egiptología Papers on Ancient Egypt}

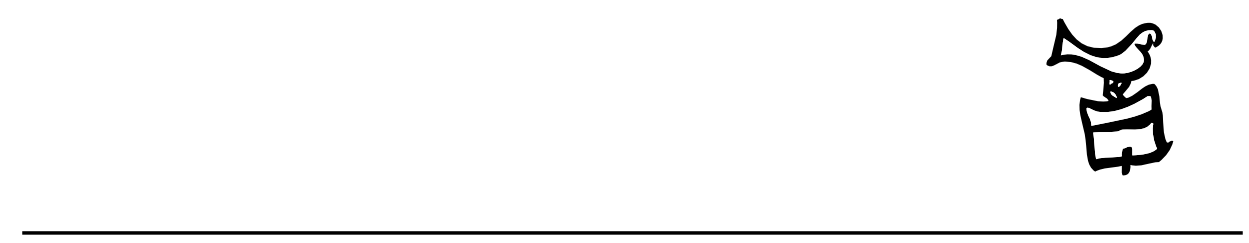

Número 5/2 2009 


\section{Actas \\ III Congreso Ibérico de Egiptología III Congresso Ibérico de Egiptologia}

Editores

Miguel Ángel Molinero Polo Covadonga Sevilla Cueva 


\title{
Editor
}

Miguel Ángel Molinero Polo

Universidad de La Laguna

\section{Consejo Editorial}

\author{
Antonio Pérez Largacha \\ Universidad de Castilla-La Mancha \\ José-R. Pérez-Accino \\ Birkbeck, Universidad de Londres \\ Covadonga Sevilla Cueva \\ Universidad Autónoma de Madrid
}

\section{Comité Científico}

Josep Cervelló i Autuori

Universitat Autònoma de Barcelona

$\mathrm{M}^{\mathrm{a}}$ José lópez Grande

Universidad Autónoma de Madrid

Josep Padró i Parcerisa

Universitat de Barcelona

$\mathrm{M}^{\mathrm{a}}$ Carmen Pérez Die

Museo Arqueológico Nacional, Madrid

Ester Pons Mellado

Museo Arqueológico Nacional, Madrid

José M. Serrano Delgado

Universidad de Sevilla

\section{Colaboradores Editoriales}

Linda Steynor

English editorial assistant

Hervé Mouriacoux

Assistant éditorial pour la langue française 
Trabajos de Egiptología está producida por Isfet. Egiptología e Historia c/ Blanco $1,2^{\circ}$

38400 Puerto de la Cruz

Tenerife-Islas Canarias

España

Maquetación: Proyecto Limón

(C) Autores de los artículos aparecidos

y Consejo Editorial de Trabajos de Egiptología - Papers on ancient Egypt

Depósito Legal: TF-2303-2009

ISSN: $1695-4750$

Imprime: Gráfica Los Majuelos, S.L.L.

imprenta@graficaslosmajuelos.com

Tfno.: 922311455 


\section{Comité Científico \\ III Congreso Ibérico de Egiptología III Congresso Ibérico de Egiptologia}

Miguel Á. Molinero Polo

Universidad de La Laguna

Presidente del Comité Organizador del III Congreso Ibérico de Egiptología

Miembro del Comité Organizador del I Encuentro de Egiptología

Josep Cervelló Autuori

Universitat Autònoma de Barcelona

Presidente del Comité Organizador del II Congreso Ibérico de Egiptologia

José Manuel Galán Allué

Consejo Superior de Investigaciones Cientificas

Director del Proyecto Djehuty, Luxor, Egipto

$\mathrm{M}^{\mathrm{a}}$ Helena Trindade Lopes

Universidad de Lisboa

Directora de la Misión Arqueológica Portuguesa en Menfis

Josep Padró i Parcerisa

Universitat de Barcelona

Director de la Misión Arqueológica de Oxirrinco

Antonio Pérez Largacha

Universidad de Castilla - La Mancha

Miembro del Comité Organizador del I Encuentro de Egiptología

José Ramón Pérez-Accino

Birkbeck College, University of London

Miembro del Comité Organizador del I Encuentro de Egiptología

$\mathrm{M}^{\mathrm{a}}$. Carmen Pérez Díe

Museo Arqueológico Nacional

Directora de la Misión Arqueológica Española en Heracleópolis Magna, Egipto

Covadonga Sevilla Cueva

Universidad Autónoma de Madrid

Miembro del Comité Organizador del I Encuentro de Egiptología 